\title{
Non Specific Motor Preparation During the Foreperiod and the Motor Action Limit
}

C.E. Van Den Heuvel and A.W.A. Van Gemmert

\section{(2) OpenEdition}

1 Journals

\section{Electronic version}

URL: http://journals.openedition.org/cpl/247

DOI: $10.4000 / \mathrm{cpl} .247$

ISSN: $1379-6100$

\section{Publisher}

Centre PsyCLÉ

Printed version

Date of publication: 1 August 2000

\section{Electronic reference}

C.E. Van Den Heuvel and A.W.A. Van Gemmert, « Non Specific Motor Preparation During the Foreperiod and the Motor Action Limit », Current psychology letters [Online], 2000/2, 2 | 2000, Online since 17 September 2003, connection on 08 September 2020. URL : http://journals.openedition.org/ cpl/247 ; DOI : https://doi.org/10.4000/cpl.247

This text was automatically generated on 8 September 2020.

(C) All rights reserved 
Non Specific Motor Preparation During the Foreperiod and the Motor Action Limit

\author{
C.E. Van Den Heuvel and A.W.A. Van Gemmert
}

